\title{
Eye Movement Analysis during Activities of Daily Living (ADL) among Fully Sighted School Children
}

(Analisis Pergerakan Mata Semasa Aktiviti Rutin Harian dalam Kalangan

Pelajar Sekolah dengan Penglihatan Normal)

\author{
ANIS SuZANnA MOHAMAD*, RifiZATI BUYONG, NORLIZA MOHAMAD FADZIL, ZAINORA MOHAMMED \\ \& MIZHANIM MOHAMAD SHAHIMIN
}

\begin{abstract}
Eye movement is one of the most important mechanisms that function to collect the information from the environment to stimulate the motor action and thus enable a person to perform daily activities. The purpose of this study was to investigate whether eye movement parameters when performing activities of daily living (ADL) is affected by learning effect when the ADL were repeated. Thirteen school children aged between 15 and 19 years old (mean $16.31 \pm 1.89$ years) participated in this study. They undergone two evaluations, baseline and follow up, separated by at least 10 weeks. The evaluation included assessment of visual acuity at near and distance using Lighthouse reduced ETDRS chart and Early Treatment Diabetic Retinopathy (ETDRS) chart, respectively; eye movement parameters (task duration, saccade latency and number of saccades) while performing ADL (identifying colours, coins and food) were recorded using Positive Science Portable LLC eye tracker. The mean value for the visual acuity at distance and near for baseline and follow up were $\log M A R-0.05 \pm 0.05$ and $\log M A R-0.05 \pm 0.05$, respectively. The results showed that comparison of eye movement parameters for performance of $A D L$ at baseline and follow up were not statistically significant. Therefore, the findings of this study suggested that learning effect is not a factor that will influence change in eye movement parameters when performing $A D L$. These findings implied some benefit in using eye movement parameters for example to evaluate performance of $A D L$ when given intervention in persons with nystagmus.
\end{abstract}

Keywords: Activities of daily living (ADL); eye movements; learning effect; saccadic eye movements

\section{ABSTRAK}

Pergerakan mata adalah salah satu mekanisme yang paling penting yang berfungsi untuk mengumpul maklumat dari persekitaran untuk merangsang tindakan motor dan dengan itu membolehkan seseorang melakukan aktiviti harian. Tujuan kajian ini adalah untuk mengkaji sama ada parameter pergerakan mata ketika melakukan aktiviti kehidupan harian (ADL) terjejas dengan kesan pembelajaran apabila ADL diulang. Tiga belas kanak-kanak sekolah berumur antara 15 dan 19 tahun (min 16,31 1.89 tahun) telah mengambil bahagian dalam kajian ini. Semua subjek menjalani dua penilaian asas dan susulan dalam tempoh sekurang-kurangnya 10 minggu. Penilaian yang dilakukan termasuk akuiti penglihatan dekat dan jauh masing-masing menggunakan carta 'Lighthouse reduced ETDRS' dan carta Rawatan Awal Diabetik Retinopati (ETDRS); parameter pergerakan mata (tempoh aktiviti, latensi sakad dan bilangan sakad) semasa menjalankan ADL (mengenal pasti warna, duit syiling dan makanan) telah direkodkan menggunakan mesin penjejak mata mudah alih LLC. Nilai min untuk akuiti penglihatan pada jauh dan dekat untuk lawatan penanda aras dan lawatan susulan

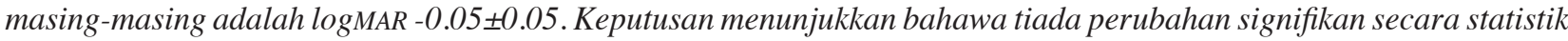
antara parameter pergerakan mata semasa ADL pada lawatan penanda aras dan lawatan susulan. Oleh itu, hasil kajian ini mencadangkan bahawa kesan pembelajaran bukanlah merupakan faktor yang akan mempengaruhi perubahan dalam parameter pergerakan mata apabila melakukan ADL. Penemuan ini memberi faedah dalam menggunakan parameter pergerakan mata sebagai contoh di dalam kajian untuk menilai prestasi ADL apabila diberi rawatan pemulihan dalam kalangan pesakit nistagmus.

Kata kunci: Aktiviti rutin harian; kesan pembelajaran; pergerakan mata; pergerakan mata sakadik

\section{INTRODUCTION}

Eye movements are one of the most important mechanisms that function to collect the information from the environment to stimulate the motor action and thus enable a person to do daily activities. Eye movements can be divided into four types: Saccadic eye movements; pursuit eye movements; vestibular eye movements; and vergence eye movements (Hertle 2002). Saccadic eye movements are classified as rapid eye movements which is responsible to maintain fixation on an object when there is stimulation on eccentric of fovea. Pursuit eye movement is slow eye movement or known as conjugate eye movement which 
is to maintain a clear image when seeing a moving object. The vestibular eye movement is a reflex eye movement that works to maintain a clear image when turning the head. A vergence eye movement is a movement of the eyes that have the ability to change the angle between the axis of vision to see near (convergence), distance (divergence) images and also for torsional (cyclovergence).

Many routine activities can be conducted with the help of vision through the mechanism of eye movement. Studies have shown that when a person does an activity, the eye will move in a series of rapid eye movement in example the action pauses saccadic or fixated. The purpose of rapid eye movement or saccadic eye movement is to bring the image of the object viewed to be formed on the fovea at the back of the eye (Ballard et al. 1995). While the action was stopped for a moment or fixation functions to minimize blur image formed at the back of the eye and thus give time to the visual system to process the input to the image seen (Turano et al. 2002). This showed that eye movements played the major role to gather information in daily routine activities.

The study of eye movements is a well-known study in recent years because eye movements play an important role in the daily activities. The study of eye movements such as eye movements during reading has begun since the 1900's. However, studies of eye movements for tasks other than reading i.e. walking, playing cricket, driving and preparing food had started after the portable eye tracker was created in the 1980s (Kandil et al. 2009; Land 2006; Land \& Hayhoe 2001; Land \& McLeod 2000; Land et al. 1999; Turano et al. 2002). Most of these studies investigate the role of eye movements while performing activities daily living (ADL).

Among the roles of eye movements that contribute to the daily routine activity is by setting the point of view in the vicinity that provides information for the next action. For example studies done by O' Regan (1990) and Taina (1995) reported that during reading, eyes will be centred on a few letters in the area which is seen to assist in the reading activity. Similarly, a study in eye movement while driving a car by Land and Lee (1994) reported that when the driver approached a corner, the view will be centred on the area around the corner to see the objects around it before proceeding. This proves that with the movement of the eyes that leads to the vicinity, information about a certain condition can be gathered and thus action that can be done well. In addition, eye movements also assist people to initially see an object before performing an action. This is evident in the study by Ballard et al. (1995) and Hayhoe et al. (1998) related with the installation of copies made of coloured blocks. In this activity, it was observed that every action that you want to do, such as choosing the block, checking the colour of the blocks and finding a position, all start with the eyes' movement of creating new fixation on the objects before an action is made. In short, the eye movement plays a big role before performing any action in the daily routine activities.
This study was conducted to investigate the effect of learning on eye movement parameters if the same activities were repeated. Previous studies have shown that there was association between memory and eye movements (Epelboim et al. 1997, 1995; Melcher \& Kowler 2001). However, those studies were conducted with adult's participants. Research by Taina and Ronan (2005) reported that there is a difference in eye movement parameter between adults and children during reading activity. Studies of eye movement in children during performance of activities of daily living were scarce. Therefore, this study was conducted on school children to investigate whether eye movement parameters while performing activities of daily living are affected by learning when the ADL tasks were repeated.

\section{Methods}

This study is a cohort study and the subjects were selected using simple sampling. The study was conducted at Optometry Clinic, Universiti Kebangsaan Malaysia for the duration of 10 months from September 2011 to June 2012. Subjects were school children from Sekolah Menengah Kebangsaan Sungai Pusu and first year Optometry student at Optometry Department, Universiti Kebangsaan Malaysia. The numbers of subjects are based on sample size calculation according to the prevalence of nystagmus in Malaysia which is $0.06 \%$ (Reddy et al. 2006). The sample size calculation for this study is based on prevalence of nystagmus because the study operated as a complementary study from the major study about nystagmus population in Malaysia. To ensure sufficient data were collected during this study, thirty-five students were screened at the start of study and those who fulfilled the inclusion criteria were invited to participate. The inclusion criteria were:

Age range from 13 to 19 years old; best corrected visual acuity of at least $6 / 6$ or better using Snellen chart with full correction; refractive power not exceeds \pm 3.00 DS for spherical component and for astigmatism component is not exceed than 1.00 DC; and good ocular health according to slit lamp biomicroscopy examination and opthalmoscopy findings.

Those who meet the criteria for this study and required correction for their refractive error were given spectacles. All subjects who required spectacles were given 2 weeks adaptation period to the spectacle before underwent tests for the baseline data. The same tests were repeated at follow up visit which was eight weeks or two months after the baseline visit.

The batteries of tests performed on all subjects at baseline and follow up visits were: visual acuity at distance (3 m) using Early Treatment Diabetic Retinopathy (ETDRS) chart; visual acuity at near $(40 \mathrm{~cm})$ using Lighthouse reduced ETDRS (Lovie-Kitchin 1988; Rosser et al. 2001); contrast sensitivity using Pelli-Robson Contrast Sensitivity Chart is used with average illumination is 422 lux. The task 
that had been chosen for eye movement testing during ADL was identifying colour pencil, coins and food. In each of these activities, the subject will be provided with two sets of the coloured pencils, coins and also pictures of the food in order. For each set of coloured pencils, coloured pencils with red, blue, black, green and yellow were arranged in a straight line. On the set of coins, the coins consist of 10,20 and 50 cents were arranged in a straight line. On the set of food, pictures of food from one meal consist of five to six foods were used. Each order is the same for each subject. Subjects were required to name the colour, coins and food showed to them. During these activities, the subject was allowed to view the tasks at their habitual distance, but subjects were reminded to maintain that distance throughout the activity. The distance used during activities and the number of error made by subjects were recorded by researchers. The same test was repeated during the follow up visit.

The eye movements of subjects during these activities were recorded using Positive Science Portable Eye Tracker. This eye tracker is an ultra-light headgear eye tracker which consisted of a headgear, two camera video and a transmitter. The headgear is a combination of two tiny cameras that are not in-contact with eyes which known as eye camera and scene camera. The monocular headgear with tiny camera is installed right before the right eye of the subjects. The eye camera installed with infrared eye camera serves to record the eye movement of the subjects. The scene camera is installed towards the area seen by the subjects in order to record the surrounding area as seen by the subjects. Videos recorded from both cameras will be synchronised using Yarbus software (Positive Science) before the eye movement video is analysed. Yarbus software calibrated the eye tracker by using seven to nine known as fixation point. This software enable to measure the gaze angle based on corneal reflection and pupil location. The video consisted of crosshairs that was superimposed at the scene camera to detect the gaze direction.

Data from the Yarbus software was analysed using Microsoft Excel 2007. Three eye movement parameters measured during the activities were task duration, saccade latency and number of saccades. Task duration is calculated based on the time taken by subjects to identify objects correctly. Saccade latency is the time taken by brain to do action points from the awareness of surrounding objects. For the saccade latency, it is calculated from the first fixation point to see the target before making the movement of the eyes to see the next target. Saccades are rapid eye movements while identifying the objects. The number of saccades were calculated when the eye movements greatly to see an object to another object. Saccadic eye movement in this video is easily observed by the movement of corneal reflex on subjects' eye. For the comparison between mean task duration, mean saccade latency and mean numbers of saccades during baseline visit and follow-up visit for each activities of this study it was analysed using the Statistical Package Social Sciences (SPSS 20.0).

\section{RESULT}

The result in Table 1 shows that mean task duration of activities undertaken by the subjects to identify the colour during baseline visit was 10197.22 \pm 9278.36 and at follow-up visit was $9525 \pm 4877.27$. Mean saccade latency taken by subjects to identify the colour of the baseline visit was $1358.19 \pm 587.06$ and at follow-up visit was $1467.00 \pm 902.08$. The mean number of saccade taken by subjects to identify the colour of the baseline visit was $11.62 \pm 5.36$ and at follow-up visit was $10.46 \pm 5.32$. Wilcoxon Signed-rank tests were performed in order to compare eye movement parameters such as task duration, saccade latency and number of saccade in identifying colour pencils between both visits. The result showed that there was no significant difference, $p>0.05$ between eye movements parameters when measuring colour pencil activities on baseline visit to follow up.

The result in Table 2 shows that mean task duration of activities undertaken by the subjects to identify the coins during baseline visit was $7773.82 \pm 2435.12$ and at follow-up visit was $10481.67 \pm 8244.96$. Mean saccade latency taken by subjects to identify the coins at the baseline visit was $1523.27 \pm 713.13$ and at followup visit was 1293.04 \pm 543.09 . Mean number of saccade taken by subjects to identify the coins of the baseline visit was $11.54 \pm 4.33$ and at follow-up visit was 9.85 \pm 4.81 . Wilcoxon Signed-rank tests and paired t-test were performed in order to compare the eye movement parameters such as task duration, saccade latency and number of saccade in identify coins between both visits.

TABLE 1. Mean task and standard deviation for task duration, saccade latency and numbers of saccade, Wilcoxon Signed-rank test result and effect size in identifying colour pencils activity between baseline visit and follow-up visit

\begin{tabular}{llccc}
\hline & & $\begin{array}{c}\text { Task duration } \\
(\mathrm{mean} \pm \mathrm{SD})(\mathrm{ms})\end{array}$ & $\begin{array}{c}\text { Saccade latency } \\
(\mathrm{mean} \pm \mathrm{SD})(\mathrm{ms})\end{array}$ & $\begin{array}{c}\text { Number of saccade } \\
(\mathrm{mean} \pm \mathrm{SD})\end{array}$ \\
\cline { 2 - 5 } & Baseline visit & $10197.22 \pm 9278.36$ & $1358.19 \pm 587.06$ & $11.62 \pm 5.36$ \\
Identify colour & Follow-up visit & $9525 \pm 4877.27$ & $1467.00 \pm 902.08$ & $10.46 \pm 5.32$ \\
pencils & Wilcoxon & $\mathrm{z}=-0.52$ & $\mathrm{z}=-0.11$ & $\mathrm{z}=-0.76$ \\
& Signed-rank test & $p=0.60$ & $p=0.92$ & $p=0.45$ \\
& Effect size & $\mathrm{r}=0.15$ & $\mathrm{r}=0.03$ & $\mathrm{r}=0.21$ \\
\hline
\end{tabular}


The result showed that there was no significant difference, $p>0.05$ between eye movements parameters when measuring coins activities on baseline visit to follow up.

The result in Table 3 shows that mean task duration of activities undertaken by the subjects to identify the foods on the baseline visit was $9482.12 \pm 2235.01$ and at follow-up visit was $9708.43 \pm 2879.49$. Mean saccade latency taken by subjects to identify the food on the baseline visit was $1601.19 \pm 754.36$ and at followup visit was $1626.69 \pm 1044.83$. The mean number of saccade taken by subjects to identify the food on the baseline visit was $15.85 \pm 8.84$ and at follow-up visit was $12.46 \pm 9.00$. Wilcoxon Signed-rank tests were performed to compare the eye movement parameters such as task duration, saccade latency and number of saccade to identify foods during both visits. The result showed that there was no significant difference, $p>0.05$ between eye movements parameters when measured coins activities during baseline visit to follow up.

\section{DISCUSSION}

The result of this study showed that all eye movement parameters measured during activity of daily living (ADL) has not change significantly when the task were repeated. This indicates that learning may not significantly influence change in eye movement parameters when performing ADL that only require looking (Epelboim et al. 1999, 1997, 1995). The finding supports previous studies reported that learning was less effective when the participants were just required to look at the task rather than doing it.

Previous study reported that eye movement was only minimally influenced by visual memory. Study by Melcher and Kowler (2001) reported that although memory for the objects seen in a scene accumulated, it was not sufficient to guide the best place to look. For instance, one of the tasks in ADL is to identify food. In this activity, subjects only required to look at a picture and naming the food. The result of the study showed that eye movement parameters measured during activity of identifying food was not change significantly when the task were repeated. The result similar to the research done by Ballard et al. (1995) in activities of copying block. The current study indicates that the subject would prefer to see the original model instead of a block of memory to replicate the original block. Thus, the researcher concluded that eye movement was only minimally influenced by visual memory.

In addition, eye movements can also be minimally affected as a result of the adaptation process (McLaughlin 1967). The current study showed that saccadic eye movements will decrease if an activity is repeated several times. This is due to the adaptation ability of corrective sacaddic eye movement every time the activity is repeated and each error that was made in fixation will be corrected with parametric changes in eye movements. However, in this study the activity was repeated by using objects with the different arrangement. It is quite different with this study. Instead of using different arrangement, no changes were made in each activities during baseline and followup visit. This suggests that adaptation process may not affected the eye movement parameters when performing ADL that only using the same arrangement. This is because the adaptation process depends on the comparison of two different images when an activity is repeated (Bahcall \& Kowler 2000).

TABLE 2. Mean task and standard deviation for task duration, saccade latency and numbers of saccade, Wilcoxon Signed-rank test result and effect size in identifying coins activity between baseline visit and follow-up visit

\begin{tabular}{|c|c|c|c|c|}
\hline & & $\begin{array}{l}\text { Task duration } \\
(\text { mean } \pm \mathrm{SD})(\mathrm{ms})\end{array}$ & $\begin{array}{l}\text { Saccade latency } \\
(\text { mean } \pm \mathrm{SD})(\mathrm{ms})\end{array}$ & $\begin{array}{c}\text { Number of saccade } \\
(\text { mean } \pm \text { SD })\end{array}$ \\
\hline & Baseline visit & $7773.82 \pm 2435.12$ & $1523.27 \pm 713.13$ & $11.54 \pm 4.33$ \\
\hline & Follow-up visit & $10481.67 \pm 8244.96$ & $1293.04 \pm 543.09$ & $9.85 \pm 4.81$ \\
\hline \multirow[t]{3}{*}{ Identify coins } & Wilcoxon Signed-rank test / & $\mathrm{z}=-1.15$ & $\mathrm{t}=0.53$ & $\mathrm{t}=1.73$ \\
\hline & Paired t-test & $p=0.25$ & $p=0.61$ & $p=0.11$ \\
\hline & Effect size & $\mathrm{r}=0.32$ & $\mathrm{~d}=0.21$ & $\mathrm{~d}=0.32$ \\
\hline
\end{tabular}

TABLE 3. Mean task and standard deviation for task duration, saccade latency and numbers of saccade, Wilcoxon Signed-rank test result and effect size in identifying foods activity between baseline visit and follow-up visit

\begin{tabular}{llccc}
\hline & $\begin{array}{c}\text { Task duration } \\
(\mathrm{mean} \pm \mathrm{SD})(\mathrm{ms})\end{array}$ & $\begin{array}{c}\text { Saccade latency } \\
(\text { mean } \pm \text { SD })(\mathrm{ms})\end{array}$ & $\begin{array}{c}\text { Number of saccade } \\
(\text { mean } \pm \text { SD })\end{array}$ \\
\cline { 2 - 5 } Identify & Baseline visit & $9482.12 \pm 2235.01$ & $1601.19 \pm 754.36$ & $15.85 \pm 8.84$ \\
foods & Follow-up visit & $9708.43 \pm 2879.49$ & $1626.69 \pm 1044.83$ & $12.46 \pm 9.00$ \\
& Wilcoxon & $\mathrm{z}=-0.04$ & $\mathrm{z}=-0.25$ & $\mathrm{z}=-1.73$ \\
& Signed-rank test & $p=0.97$ & $p=0.81$ & $p=0.08$ \\
& Effect size & $\mathrm{r}=0.01$ & $\mathrm{r}=0.07$ & $\mathrm{r}=0.48$ \\
\hline
\end{tabular}


Besides that, previous study reported that eye movement were also influence the visual habit. In study done by O' Regan et al. (2000), it was stated that everything that is seen is not necessarily seen. This study states that any changes in position of an object by only 1 degree, more than $40 \%$ of subjects were unable to identify the changes. This clearly shows that if no obvious changes occurred on an object that was seen before, the eye movement cannot detected the changes. In this study, no changes were made in each activities during baseline and follow-up visit. This suggests that visual habit may not affected the eye movement parameters when performing ADL when the same arrangement was used. Therefore, it showed no learning effect obtained by the subjects if the activity is repeated.

Despite that, previous studies also reported that eye movement can be affected by the level of attention among the subject (Triesch et al. 2000). In this study it shows that an activity would be more accurate if the subjects stayed focus to the task. It showed that the frequency of looking at an object does not influenced the precision to do particular activities. For example, in this study, the eyes will look towards the right color pencils when directed to do so and this is not the result of the frequency of the subject make these activities. Therefore, it suggest that attention play major role in influencing the eye movement in ADL rather that the frequency of doing particular activities. Thus, the frequency of doing ADL showed no learning effect obtained if the activity is repeated.

\section{CONCLUSION}

In nutshell, learning has a very minimal influence in eye movement when the tasks only require looking. These findings suggest that learning may not significantly influence change in eye movement parameters when performing ADL that only require looking. Therefore the finding of this study may be valuable in future study to use eye movements as a tool to infer impact of rehabilitation.

\section{ACKNOWLEDGEMENTS}

It is great honour to thank those who gave me invaluable support and guidance throughout this project. To my supervisors, co-supervisors, all staff from the Optometry Department UKM and SMK Sungai Pusu, School of Psychology, University of Nottingham, Malaysia Campus, my dearest thesis colleague, thanks for being so cooperative and helpful in assisting me to complete this project.

\section{REFERENCES}

Bahcall, D.O. \& Kowler, E. 2000. The control of saccadic adaptation: Implications for the scanning of natural visual scenes. Vision Research 40(20): 2779-2796.
Ballard, D., Hayhoe, M. \& Pelz, J. 1995. Memory representations in natural tasks. Cognitive Neuroscience 7: 66-80.

Epelboim, J., Steinman, R., Kowler, E., Edwards, M., Pizlo, Z., Erkelens, C.J. \& Collewijn, H. 1995. The function of visual search and memory in sequential looking tasks. Vis Res. 35: 3401-3422.

Hayhoe, M.M., Bensinger, D.G. \& Ballard, D.H. 1998. Task constraints in visual working memory. Vision Research 38: 12-137.

Hertle, R.W. 2006. Supranuclear Eye Movement Disorders, Acquired and Neurological Nystagmus. Eye movements and strabismus. Elsevier Steven Ltd 790-811.

Kandil, F.I., Rotter, A. \& Lappe, M. 2009. Driving is smoother and more stable when using the tangent point. Journal of Vision 9(1): 1-11.

Land, M., Mennie, N. \& Rusted, J. 1999. The roles of vision and eye movements in the control of activities of daily living. Perception 28(11): 1311-1328.

Land, M.F. \& Hayhoe, M. 2001. In what ways do eye movements contribute to everyday activities? Vision Research 41(25-26): 3559-3565.

Land, M.F. \& McLeod, P. 2000. From eye movements to actions: How batsmen hit the ball. Nature Neuroscience 3: 1340-1345.

Land, M.F. \& Lee, D.N. 1994. Where we look when we steer. Nature 369(6483): 742-744.

Land, M.F. 2006. Eye movements and the control of actions in everyday life. Journal of Science Direct 25: 296-324.

McLaughlin, S.C. 1967. Parametric adjustment in saccadic eye movements. Perception \& Psychophysics 2: 359-361.

Melcher, D. \& Kowler, E. 2001. Visual scene memory and the guidance of saccadic eye movements. Vis Res. 41: 3597-3611.

O’Regan, J.K. 1990. Eye movements and reading. In Eye Movements and Their Role in Visual and Cognitive Processes, edited by Kowler, E. Amsterdam: Elsevier Science Publishers. pp. 99-435.

Taina, M.L. \& Ronan, G.R. 2005. Improving eye movement control in young readers. Artificial Intelligence Review 24: 477-488.

Turano, K.A., Geruschat, D.R. \& Baker, F.H. 2002. Fixation behavior while walking: Persons with central visual field loss. Vision Research 42(23): 2635-2644.

Optometry and Visual Science Programme

School of Healthcare Sciences

Universiti Kebangsaan Malaysia

Jalan Raja Muda Abdul Aziz

50300 Kuala Lumpur, Wilayah Persekutuan

Malaysia

*Corresponding author; email: anis.suzanna@yahoo.com

Received: 18 April 2013

Accepted: 25 May 2015 